\title{
Teknologi Intelegent Mobility
}

\author{
Akhmad Amajid \\ Mahasiswa Program Studi Mesin Otomotif, \\ Fakultas Teknik, Universitas Muhammadiyah Magelang
}

\section{RINGKASAN}

Konsep intelligent mobility telah dikenalkan dan dikomersialkan untuk membantu para konsumen dalam mengendarai kendaraan lebih mudah [1]. Dengan teknologi ini kendaraan dapat menjadi mitra bukan hanya sebagai alat transpoortasi saja. Kendaraan dikembangkan lebih mirip seperti robot yang memudahkan dalam manusia menjalankan akivitas. Teknologi yang ditawarkan intelligent mobility diantaranya ada beberapa yang sudah pada produksi massal, aplikasi, prototipe, model maupun paripurwa.

\section{PENDAHULUAN}

Perkembangan teknologi otomotif pada era Revolusi Industri 4.0 sebagian besar mengarah pada teknologi digital baik berkembang pada sistem sensor, penyimpan data maupun sistem pengendali dengan intelligent control atau intelligent mobility. Keberadaan teknologi ini dapat meningkatkan efisiensi bahan bakar, kenyamanan berkendara, keamanan berkendaraa maupun pretise pengguna kendaraan.

\section{Intelligent Mobility sebagai mitra manusia}

Berfungsi sebagai mitra manusia dimana kendaraan menjalankan perintah sesuai interaksi dengan pengendara. Hal ini memudahkan pengendara lanjut usia (lansia) yang kesulitan mengendarai dengan baik atau orang yang difabel. Intelligent Mobility dapat berfungsi teknologi propilot dimana desain interior dapat menyandarkan semua kursi dan kembali seperti semula secara otomatis. Dengan 
demikian pengendara lebih leluasa dalam berkendara. Membangun kenyamanan ruang dalam mobil agar terlihat lebih luas.

\section{Menjadi bagian dari infrastruktur sosial}

Intelligent Mobility dapat meberikan layanan pada pengendara ke daerah khusus misalnya parkiran. Hal ini karena intelligent mobility dapat terhubung terhadap jaringan listrik lokal dan bertindak sebagai pembangkit listrik "virtual" dengan mengembalikan listrik ke jaringan., Pengembangan sistem dengan fitur vehicle-to-home dan vehicle-to-building. Seluruh proses dilakukan secara efisien untuk peningkatan kapasitas baterai dan teknologi mobil terkoneksi.

\section{Pengendali engine, pemindah tenaga maupun safety system}

Intelligent mobility dapat memonitor perilaku pengendara kendaraan untuk mencegah kecelakaan secara dini dengan metode penginderaan jarak jauh [2]. Baru baru ini intelligent mobility sudah mampu mengendalikan kendaraan secara autopilot maupun autonomous [3][4][5]. Autopilot pada kendaraan memberikan kenyamanan pada pengendara, dimana kendaraan dapat bekerja sendiri (self-driving). Pengembangan konsep teknologi ini mengacu pada teknologi driving yang diembededkan pada pesawat terbang. Teknologi autopilot masih memerlukan driver dalam menjalankan kendaraan, sehingga teknologi bekerja sebagai teknologi pembantu driver/pengendara. Autonomous mulai dikembangkan saat ini. Teknologi ini dikembangkan sudah tidak membutuhkan pengemudi. Kendaraan akan dikendalikan melalui radar, sehingga bekerja layaknya pesawat drone yang bekerja dengan sendirinya. Namun, teknologi autonomous masih memiliki segudang permasalahan terutama factor tabrakan yang terjadi di jalan raya [6].

Pengembangan intelligent mobility juga mengarah pada fasilitas assories kendaraan.

\section{a. Intelligent Rear View Mirror (IRVW)}


Penggunaan IRVW ini berfungsi untuk melihat dengan jelas keadaan belakang mobil, sehingga pengendara tanpa terhalangi aksesori mobil maupun penumpang. Fitur ini sangat membantu untuk penderita Miopi, dikarenakan kesulitan melihat dalam jarak jauh. Teknologi ini dapat dikendalikan dengan menghidupkan melalui tombol atau switch. Ketika intelligent rear view mirror telah aktif, kamera akan menyala dan membantu pengendara melihat situasi di belakang kendaraan dengan jelas.

\section{b. Blind Spot Warning (BSW)}

Fitur ini sangat membantu bagi pengendara ketika pengendara menginginkan untuk pindah jalur ketika beroperasi di jalan raya dengan mudah. BSW akan membuat pengendaraa tetap terjaga dan mengingatkan pengendara jika ada kendaraan yang datang dari titik yang berbahaya. Blind spot warning digunakan pengendara lain untuk menyalip saat berada di jalur tol. Secara otomatis kesulitan berkendara untuk pengendara yang memiliki mata minus dapat dibantu oleh teknologi ini. Deteksi sensor yang mencapai jangkauan beberapa meter sangat membantu penderita miopi, hipermetropi, atau bahkan presbiopi (mata tua).

\section{c. Lane Departure Warning (LDW)}

Teknologi LDW yang disediakan bagi pengendara untuk memastikan saat pindah jalur. Saat kendaraan mulai keluar dari marka jalan sistem akan bekerja memberi peringatan. LDW sangat membantu bagi penderita presbiopi yang mana kesulitan untuk berkendara secara seimbang dan berada tetap pada marka jalan. Teknologi Intelligent Mobility yang sudah diaplikasikan dalam kendaraan memiliki spesifikasi tertentu tergantung kapasistas yang dirancang. Secara illustrasi teknologi ini dapat terlihat dalam gambar 1. 


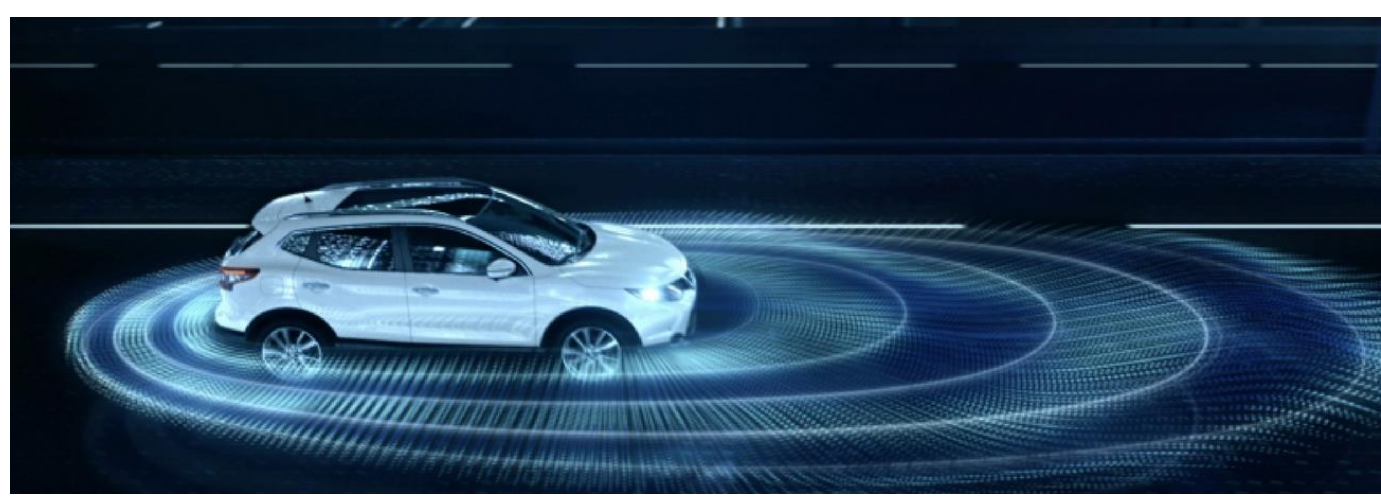

Gambar 1. Teknologi jangkauan intelligent mobility yang sudah diaplikasikan dalam kendaraan [7].

\section{Kesimpulan}

Dengan teknologi intelligent mobility akan sangat membantu membantu pada pengendara dari segi penghematan energi, kenyamanan pengendara, keamanan pengendara bahwa dapat menambah prestise. Penemuan - penemuan teknologi intelligent mobility akan berdampak pada persaingan industry otomotif baik secara nasional maupun global.

\section{Referensi}

[1] G. M. Nayazri, "Lewat 'Intelligent Mobility', Buat Nissan Beda dari Kompetitor Artikel ini telah tayang di Kompas.com dengan judul 'Lewat 'Intelligent Mobility', Buat Nissan Beda dari Kompetitor', Penulis :," Kompas.com, 2017. .

[2] H. Fahrian, S. Munahar, and D. S. Putra, "Pengembangan Sirkuit Security System untuk Meningkatkan Driver Behaviour Control pada Kendaraan," Automotive Experiences, vol. 1, no. 01, pp. 13-19, 2018.

[3] R. Bastam, "Ini 6 Perbedaan Mobil Autopilot dan Autonomous," IDM Time, 2017.

[4] S. Akib, “Daftar Merek yang Mempersiapkan Mobil Autopilot,” IDM Time, 2017.

[5] Kompas, "Mobil Autopilot Tesla Ternyata sudah Diuji Coba di Jalanan Jakarta Artikel ini telah tayang di Tribunnews.com dengan judul Mobil Autopilot Tesla Ternyata sudah Diuji Coba di Jalanan Jakarta," Trinbunotomotif, 2016. .

[6] A. Wirjaputra, "MENGUNGKAP TEKNOLOGI 'GOOGLE AUTONOMOUS CAR,'" Binus University, 2012.

[7] P. Nissan, “2019 Nissan Intelligent Mobility technology features," Pentiction Nissan, 2018. 